J. Lake Sci. (湖泊科学), 2018, 30(1): 57-69

DOI 10. 18307/2018. 0106

(c) 2018 by Journal of Lake Sciences

\title{
多源水联合调度重构滇池流域健康水循环模式”
}

\author{
陈 刚 $^{1,2}$, 桑学锋 ${ }^{3}$, 顾世祥 ${ }^{2 * *}$, 杨 霄 $^{2}$, 周祖昊 ${ }^{3}$, 李游洋 ${ }^{2}$ \\ ( 1 : 河海大学水文水资源与水利工程科学国家重点实验室,南京 210098) \\ ( 2 : 云南省水利水电勘测设计研究院, 昆明 650021) \\ (3: 中国水利水电科学研究院, 北京 100038 )
}

\begin{abstract}
摘 要: 河湖生态用水被挤占并严重短缺是滇池水污染严重和恶化趋势难以遏制的根本原因之一. 在对滇池流域“自然 一人工”二元水循环结构剖析的基础上,结合滇池治理 “六大工程” 实施现状及存在问题, 以水资源的高效配置和循环利 用为核心, 提出了重构滇池流域健康水循环的总体框架. 在水资源模拟系统 MIKE BASIN 平台上, 通过水力联系将环湖截 污、外流域调水与节水、人湖河道整治、农业农村面源治理、生态修复、生态清淤等整合为一个有机整体, 以恢复流域自然 水系循环为目标, 将外流域引调水与本区水库水、滇池水、地下水、城市再生水等多源水资源进行水量和水质统一配置, 得到滇池流域水资源总体配置方案. 结果表明:在牛栏江向滇池年均补水 5.72 亿 $\mathrm{m}^{3}$ 的前提下,昆明城市尾水可以全部直 接外排至下游作为工业用水,削减滇池人湖污染负荷, 从而加速滇池生态环境修复的进程.
\end{abstract}

关键词: 滇池流域;跨流域调水;水污染控制;水量平衡;联合调度

\section{Joint disposals of multi-source water resources for rehabilitating healthy water cycle in Lake Dianchi Basin}

CHEN Gang ${ }^{1,2}$, SANG Xuefeng ${ }^{3}$, GU Shixiang $^{2 * *}$, YANG Xiao $^{2}$, ZHOU Zuhao $^{3}$ \& LI Youyang ${ }^{2}$

( 1 : State Key Laboratory of Hydrology-Water Resources and Hydraulic Engineering, Hohai University, Nianjing 210098, P.R. China)

(2: Yunnan Survey and Design Institute of Water Conservancy and Hydropower, Kunming 650021, P.R. China)

(3: China Institute of Water Resources and Hydropower Research, Beijing 100038, P.R.China)

Abstract: Ecological water of Lake Dianchi and its inflowing rivers has been occupied and experiences serious shortage, which is one of the fundamental causes of serious water pollution with worsening trend and difficult to be constrained. Based on the analysis of natural-social dualistic water cycles, together with the construction of the water pollution prevention system in the basin, this paper presents a framework of healthy water cycle and takes MIKE BASIN as the simulation platform to integrate lake sewage interception, in-lake ecological restoration, lakebed sludge dredging, agricultural non-point sources management, and inflowing river renovation as an organic whole. Centred on the guarantee of residential water, industrial water, irrigation water and ecological water, joint disposals of multi-source water resources are adopted to meet the water demands of Lake Dianchi and its inflowing rivers. Moreover, function orientation of urban river clarifies the route of sewage treatment and circulating utilization. Taking water balance of Lake Dianchi as a premise, the tail water of the municipal sewage of Kunming City is supposed to discharge outside the basin as far as possible. Simulated results indicate that if multi-year average $5.72 \times 10^{8} \mathrm{~m}^{3}$ water is transferred to Lake Dianchi, all recycled water may be deployed towards the downstream Anning-Fumin industrial corridor as industrial water.

Keywords: Lake Dianchi Basin; inter-catchment water diversion; water pollution control; water balance; joint disposals

在全球气候变化和高强度人类活动的共同影响下, 湖泊流域面临着水资源短缺、水环境恶化及生态退

* 云南省基础研究重点项目(2017FA022) 和国家水体污染控制与治理科技重大专项(2013ZX07102-006) 联合资助. 2016-07-11 收稿; 2017-04-27 收修改稿. 陈刚 (1984 ), 男,博士研究生,工程师; E-mail: zxm_232000@163. com.

** 通信作者; E-mail: gushxang@ qq.com. 
化等一系列水问题 ${ }^{[-2]}$. 水循环承载着地球上各种形式水的形成和转化, 并与水环境、水生态等过程相互作 用 ${ }^{[3]}$. 尽管在不同的流域这些水问题的表现形式不尽相同,但都可归结于流域水循环过程的演化. 因此,对 以水循环为纽带的复杂系统进行综合调控,协调处理好水循环过程中水资源、水生态、水环境 3 大核心系统 间的相互关系,维持健康的水循环过程, 是解决当前湖泊流域面临的水问题的根本途径 ${ }^{[4-5]}$.

国内健康水循环的研究主要集中在城市水系统方面. 张杰提出了“城市水系统健康循环”, 并被写人《国 家中长期科学和技术发展规划 $(2006-2020) 》$, 作为城市水环境恢复的指导思想 ${ }^{[6]}$. 目前已应用于深圳、大 连、北京、广州等城市水资源与水环境的战略规划 ${ }^{[7-8]}$. 城市健康水循环就是将循环经济减量、再利用、再循 环的 3R 原则融人水资源开发利用之中, 使水资源利用方式从 “供一用一耗一排” 单向开放型流动, 转变为 “节 制取水一节约用水一再生循环” 反馈式循环流程, 确保水的社会循环不损害其自然循环的规律, 维系或恢复 城市及流域健康水环境 ${ }^{[9]}$. 为应对城市化进程对水环境的负面影响, 国际上逐步将低冲击式开发模式、可持 续城市排水系统、低影响城市设计等技术融合, 形成水敏型城市设计的理论框架 ${ }^{[10-12]}$, 并已在丹麦、美国、澳 大利亚等国家实践, 核心理念与国内的城市健康水循环基本相同. 在探究我国湖泊保护策略的研究中, 许多 学者提出建立流域健康水循环的建议 ${ }^{[1,13]}$, 但健康水循环应用于湖泊流域生态环境保护和修复的研究还鲜 有报道.

随着 1980s 以来流域社会经济的快速发展、人口快速增长和城市规模的急剧扩张, 滇池及其主要人湖河 流水质一直处于劣 $\mathrm{V}$ 类, 面临严重的水生态环境问题, 成为国家重点治理的流域之一 ${ }^{[14-15]}$. “十一五” 以来, 滇池治理力度不断加大, 全面实施了环湖截污、农业农村面源治理、生态修复与建设、入湖河道整治、生态清 淤和外流域调水及节水等一系列滇池治理工程. 目前, 滇池治理的 “六大工程”已基本建成, 滇池水体水质与 湖滨环境明显改善 ${ }^{[16]}$, 但治理成效与公众期望仍有较大差距 ${ }^{[17]}$. 究其原因, 滇池治理各项工程处于独立运 行状态, 尚未形成滇池综合治理的系统最大 “合力”. 本文在系统诊断流域水问题及其综合治理措施现状调 查的基础上, 在流域尺度上延伸城市健康水循环的核心理念, 以水循环为纽带, 将滇池治理 “六大工程” 整合 为一个系统, 实现流域内多源水资源的联合调度, 重构滇池流域健康水循环模式.

\section{1 研究方法}

\section{1 流域健康水循环的内涵和实现途径}

1.1.1 流域健康水循环的内涵 构建流域健康水循环的总体目标是在资源和环境约束趋紧的背景下, 通过合 理配置流域内有限的水资源, 实现流域内多源水的联合调控, 改善区域生态环境, 促进以水循环为纽带的水 资源、社会经济、生态环境 3 大系统间的协调可持续发展.

流域健康水循环是指在流域的整体视角下, 以“减量化、再利用、资源化”为原则,通过水资源的高效配 置和循环利用, 尽量避免对自然水循环造成不必要的干扰和破坏, 维系自然生态平衡. 社会水循环的综合调 控是构建流域健康水循环的出发点, 在循环过程上注重闭路循环的健全, 通过节水减排 (减量化) 、一水多用 (再利用) 和污水处理回用 (资源化), 减少清洁水资源的需求和污染负荷的排放, 减少人类活动对自然水循 环的干扰和破坏. 促进水的良性循环是构建流域健康水循环的目的, 通过自然水的良性循环满足生态环境 系统需求, 通过社会水的良性循环支撑社会经济系统的用水需求, 从而促进水资源、社会经济和生态环境的 协调可持续发展.

1.1.2 流域健康水循环的实现途径 以滇池流域为例, 在滇池流域的水循环中, 河湖是水和物质的输运通道, 水库、(污水) 水厂是受人工控制的循环节点, 依托江河湖库水系连通, 优化库、厂等控制节点的运行调度, 改 善水和物质循环的路径和通量, 实现流域内水库水、湖泊水、河流水、外调水、再生水等多源水的联合调度, 恢复流域自然水系循环. 具体实施步骤为: 1) 对社会经济、水生态、水环境等子系统进行调查评价, 明确各子 系统不同规划期对水资源质和量的需求, 作为方案比选的边界条件;2)调查流域水资源系统, 明确每一个可 人工干预节点的调控方案集, 作为方案比选的可行域; 3) 通过对自然水循环和社会水循环的调查, 在流域尺 度上明晰每一类水的循环路径和通量, 按照健康水循环的理念, 厘清各类工程的调控方案, 整合得到流域健 康水循环的总体框架;4) 在总体框架的指导下, 拟定流域多源水资源的综合调控方案, 确定各类水源工程的 供水方案; 5) 选取合适的数学模型对需求侧 (社会经济发展需水、生态环境需水) 和供给侧 (各类水源工程的 
供水方案) 进行数学概化, 根据流域水资源管理的要求, 拟定目标函数和情景方案, 优化模拟得到各子系统 的协调可持续发展的方案.

根据滇池流域水资源管理的要求, 以缺水率最小、公平性最优、水功能区达标率最高、滇池水量平衡为 优化目标,构建流域健康的实现途径和实施步骤,本研究的技术路线如图 1 所示.

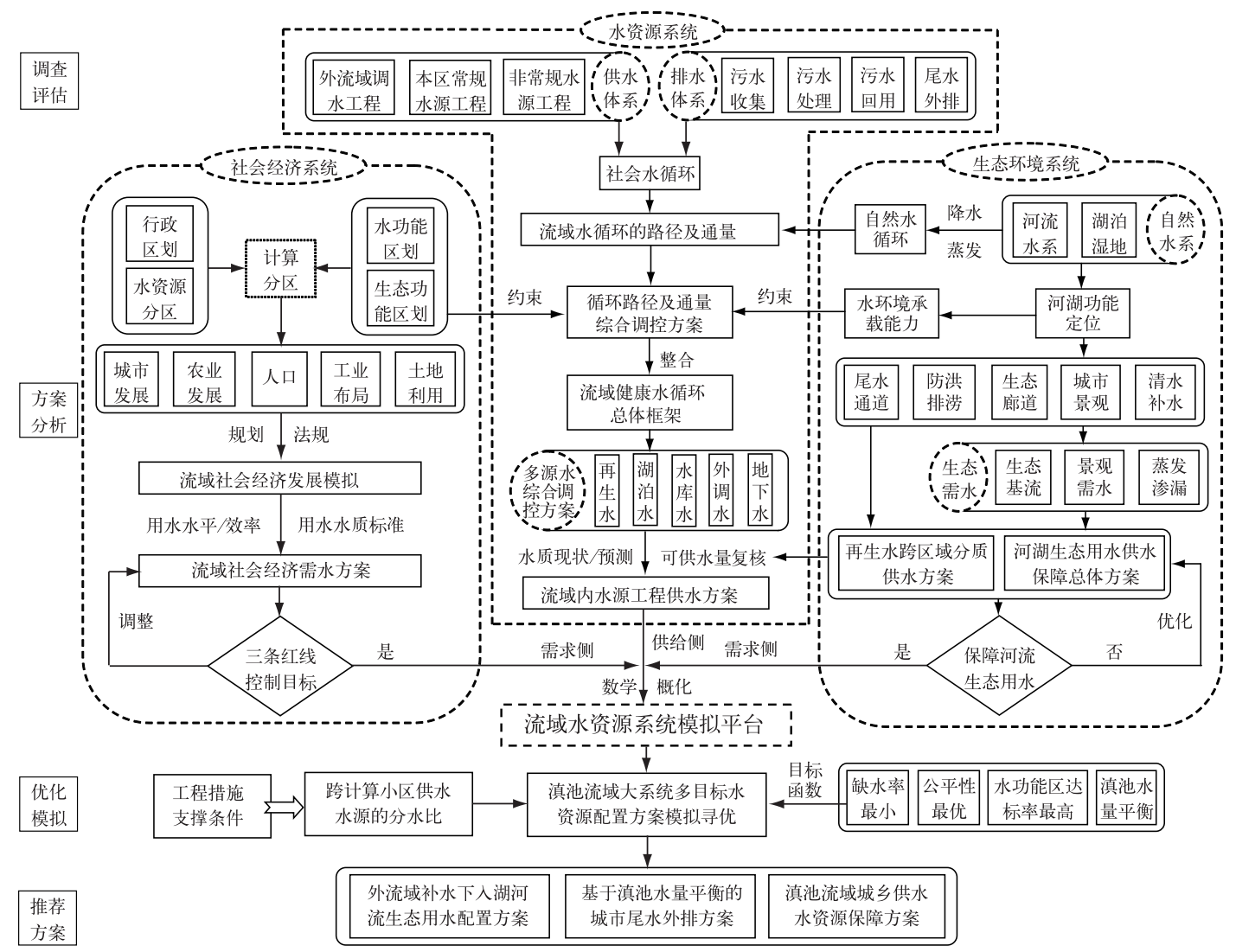

图 1 滇池流域多源水资源系统配置技术路线

Fig.1 Methodological framework for joint disposals of multi-source water resources in Lake Dianchi Basin

\section{2 滇池流域水资源系统现状调查}

1.2 .1 研究区域简介滇池流域 $\left(24^{\circ} 29^{\prime} \sim 25^{\circ} 28^{\prime} \mathrm{N}, 102^{\circ} 29^{\prime} \sim 103^{\circ} 01^{\prime} \mathrm{E}\right)$ 位于云南省中部. 流域属亚热带季风 气候带, $1953-2015$ 年的多年平均气温为 $15.15^{\circ} \mathrm{C}$, 多年平均降水量为 $984.20 \mathrm{~mm}$, 其中 $80 \%$ 降水量集中在 6-10月,年内分布极其不均 ${ }^{[18]}$. 流域位于国家城镇化发展 “包昆通道” 纵轴的南端, 流域内滇中城市群的核 心城市一一昆明市环滇池而建. 2015 年流域内总人口 382.28 万人, 其中城镇人口 353.31 万人, 城镇化率 $92.4 \%$. 地区生产总值 3031 亿元, 占云南省同期值的 $22.9 \%$, 是云南省社会经济最发达、人口最密集的 区域 ${ }^{[14]}$.

1.2 .2 流域自然水系 滇池流域是长江水系普渡河流域上游段, 流域面积 $2920 \mathrm{~km}^{2}$, 为南北长、东西窄的湖盆 地形,盆地四周为山地地貌, 盆地内为堆积地貌, 西南为构造断陷湖一一滇池. 盘龙江等 29 条河流呈向心状 汇人滇池,集雨面积共计 $2351 \mathrm{~km}^{2}$, 占滇池流域陆域面积的 $90.0 \%$, 是滇池主要的水量来源 ${ }^{[19]}$.

滇池是云贵高原上最大的淡水湖泊, 湖面南北平均长 $40.4 \mathrm{~km}$, 东西平均宽 $7.0 \mathrm{~km}$, 湖岸线长 $163.2 \mathrm{~km}$, 平均水深 $5.24 \mathrm{~m}$. 水位为 $1887.50 \mathrm{~m}$ 时, 湖面面积为 $309.50 \mathrm{~km}^{2}$, 湖容 16.23 亿 $\mathrm{m}^{3}$. 滇池运行水位受人工控 制, 正常高水位为 $1887.50 \mathrm{~m}$, 最低工作水位 $1885.50 \mathrm{~m}$, 调节湖容 6.18 亿 $\mathrm{m}^{3}$. 滇池水域被海埂闸人为分隔为 
草海和外海两部分. 草海湖面面积 $11 \mathrm{~km}^{2}$ (水位 $1887.50 \mathrm{~m}$ ), 平均水深 $2.61 \mathrm{~m}$, 湖容仅 0.29 亿 $\mathrm{m}^{3}$, 但承纳了 昆明市大部分的城市污水, 湖水基本由人工开丵的西园隧洞排人螳螂川 ${ }^{[20]}$. 外海湖面面积 $298 \mathrm{~km}^{2}$, 平均水 深 $5.34 \mathrm{~m}$, 湖水由海口河汇人螳螂川, 最终注人金沙江.

1.2.3 水资源开发利用及存在问题 为了支撑昆明城市的发展和流域内生产生活用水, 滇池流域已建成蓄水 工程 167 座, 其中大中型水库 8 座, 小 (一) 型水库 29 座, 小 (二) 型水库 130 座, 小坝塘 445 座, 控制径流面 积 $1616 \mathrm{~km}^{2}$, 总库容 4.36 亿 $\mathrm{m}^{3}$, 兴利库容 2.73 亿 $\mathrm{m}^{3}$; 小型河道引水工程 110 件, 地下水井工程 134 座. 为了 缓解滇池流域水资源短缺的问题, 相继实施了掌鸠河引水供水工程、清水海引水工程、牛栏江一滇池补水工 程等“引水济昆”工程,设计供水量分别为 $2.20 、 0.97$ 和 5.72 亿 $\mathrm{m}^{3[21]} .2007$ 年 3 月掌鸭河引水工程建成通水 后, 滇池不再作为昆明城市供水的常规水源, 但仍为湖滨农田的灌溉水源, 现建有提灌百站 276 座, 设计灌 溉面积 1.13 万 $\mathrm{hm}^{2[19]}$.

滇池流域自产水资源量为 5.55 亿 $\mathrm{m}^{3}$, 人均水资源量不足 $200 \mathrm{~m}^{3} /$ 人, 即使加上外调水量 8.89 亿 $\mathrm{m}^{3}$, 人 均水资源量仍低于国际公认 $500 \mathrm{~m}^{3} /$ 人的水危机红线. 2015 年滇池流域总供水量 8.20 亿 $\mathrm{m}^{3}$, 其中本区水库 供水 3.10 亿 $\mathrm{m}^{3}$, 滇池供水 1.36 亿 $\mathrm{m}^{3}$, 本区水资源开发利用率高达 $91.0 \%$,生产生活用水严重挤占河湖生态 用水.

1.2.4 水污染防治工程体系及存在问题 滇池水污染治理始于 $1980 \mathrm{~s}$ 后期, 随着水污染问题的加剧, 滇池治 理经历从单一工程措施向工程措施与非工程措施相结合综合治理转变, 治理力度不断加大 ${ }^{[13]}$. “十一五” 期 间, 提出了以“六大工程”为主线的综合治理方略, 并在 “十二五” 期间进行了巩固提升, 取得了阶段性成效, 水质恶化趋势基本被遏制. 但是, 湖体水质至今仍未根本好转, 滇池治理仍任重道远 ${ }^{[15,22]}$. 滇池水环境综合 治理的工程体系虽渐成倠形,但各自独立运行, 缺乏相互联系和功能的系统集成 (表 1).

此外, 为防治滇池水污染和缓解流域水资源短缺的问题, 昆明市调整了滇池流域的产业结构与布局, 将 高耗水、高污染的产业转移至下游安宁一富民工业走廊. 经过多年发展, 2015 年国务院已批复在此设立国家 级产业新区一一滇中新区.

\section{3 流域健康水循环总体框架}

1.3.1 总体思路 通过对滇池流域水资源系统调查评价, 按照流域健康水循环的理念和技术路线, 主要从以 下几个方面来构建滇池流域的健康水循环: (1)明确人湖河流功能定位, 确定人湖河流的受纳水源, 即清水廊 道和尾水通道. (2)清水廊道采用水库和牛栏江外调水为补水水源, 通过水库生态调度和水系连通工程, 实现 牛栏江一滇池补水工程 “多口补滇”, 保障清水廊道的生态用水. (3)尾水通道受纳处理后的城市生活污水、城 市初期雨水以及农业面源污水, 最后截至环湖截污干管直接外排出滇池流域, 作为滇池下游安宁一富民工业 走廊的消耗性工业用水. (4)加强环湖湿地 (属生态修复与建设工程) 与人湖河流的水路连通, 充分发挥其作 为滇池最后一道保护屏障的作用,削减难以收集的中后期雨水和农业面源污染负荷.

1.3.2 滇池流域健康水循环总体框架 在流域二元水循环总体框架的基础上, 延伸城市健康水循环的理念, 按照总体思路及滇池治理 “六大工程” 整合方案, 提出多源水联合调度重构滇池流域健康水循环的总体框架 (图 2).

为了厘清研究区域内不同水质水资源的循环路径,在蓝水、绿水划分标准的基础上,定义自然水体在河 流、地下含水层、水库和湖泊中储存, 以及蒸发、降水、产汇流过程为蓝水循环; 将水质达到地表 III 类及其以 上的清洁水体经过人工调控、输送的过程定义为清水循环; 将城市和农村污水的收集、处理、输送及再生利 用过程定义为再生水循环. 如图 2 所示, 区域内的蓝水循环与二元水循环中的自然水循环基本重合, 遵循 “生态优先” 的准则, 加上生物体、土壤水后属于大尺度的“五水” 转化; 再生水循环为人工侧支循环, 遵循 “节水优先” 的准则, 在本流域和跨区域封闭循环; 清水循环则通过城乡供水、水系连通、生态用水替代调度 等方式将自然水循环与人工水循环联系起来, 也将滇池治理 “六大工程” 整合成为有机整体, 通过实施人工 干预和调控,重构流域健康水循环模式.

\section{4 滇池流域各子系统的需求}

1.4.1 社会经济系统 本研究中确定 2 个规划期: 近期 2020 年, 远期 2030 年. 根据宏观经济发展规划, 2020 年滇池流域社会经济需水 8.97 亿 $\mathrm{m}^{3}$, 其中城乡生活 4.42 亿 $\mathrm{m}^{3}$, 工业 2.55 亿 $\mathrm{m}^{3}$, 农业灌溉 2.00 亿 $\mathrm{m}^{3} ; 2030$ 


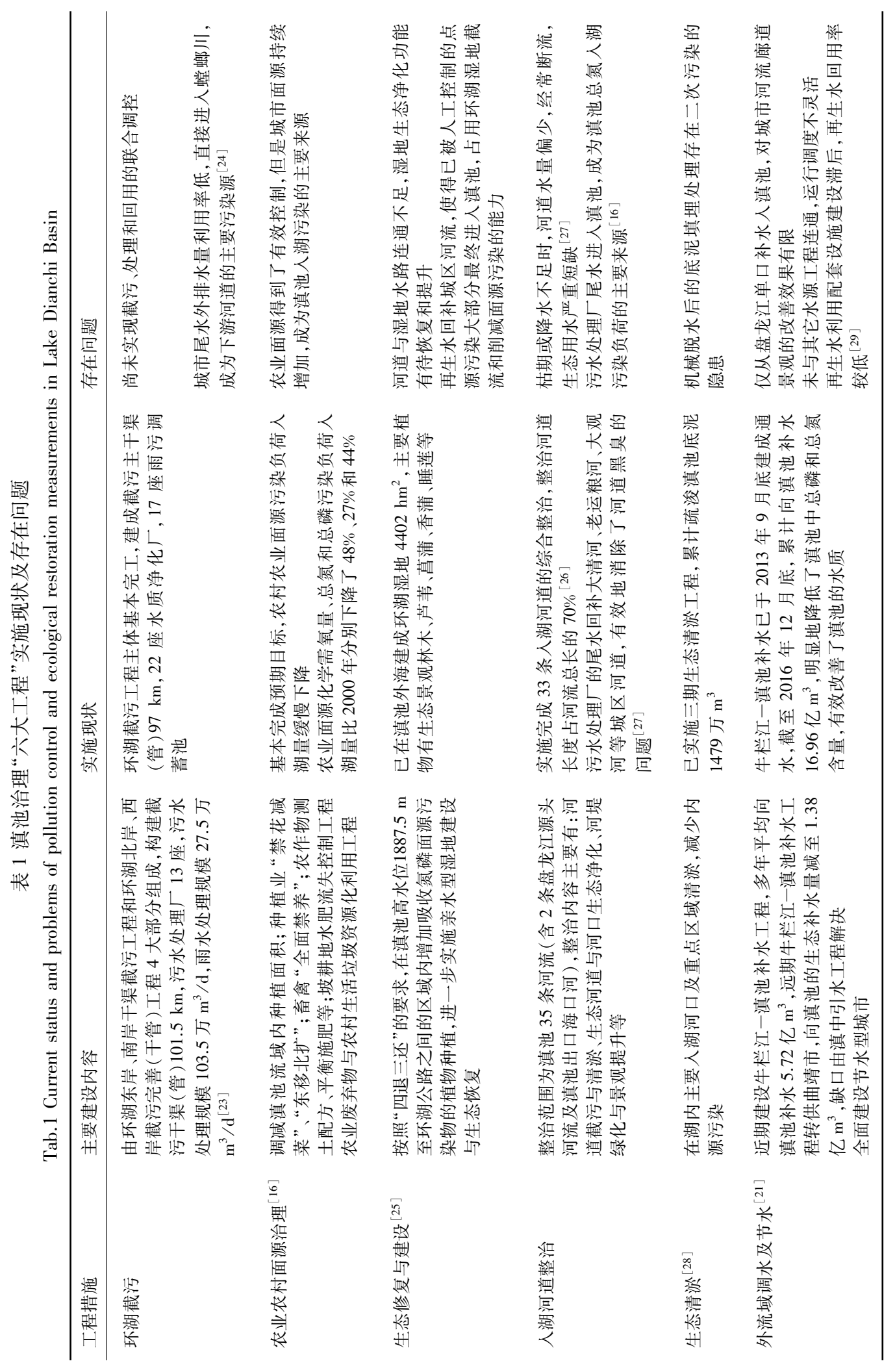




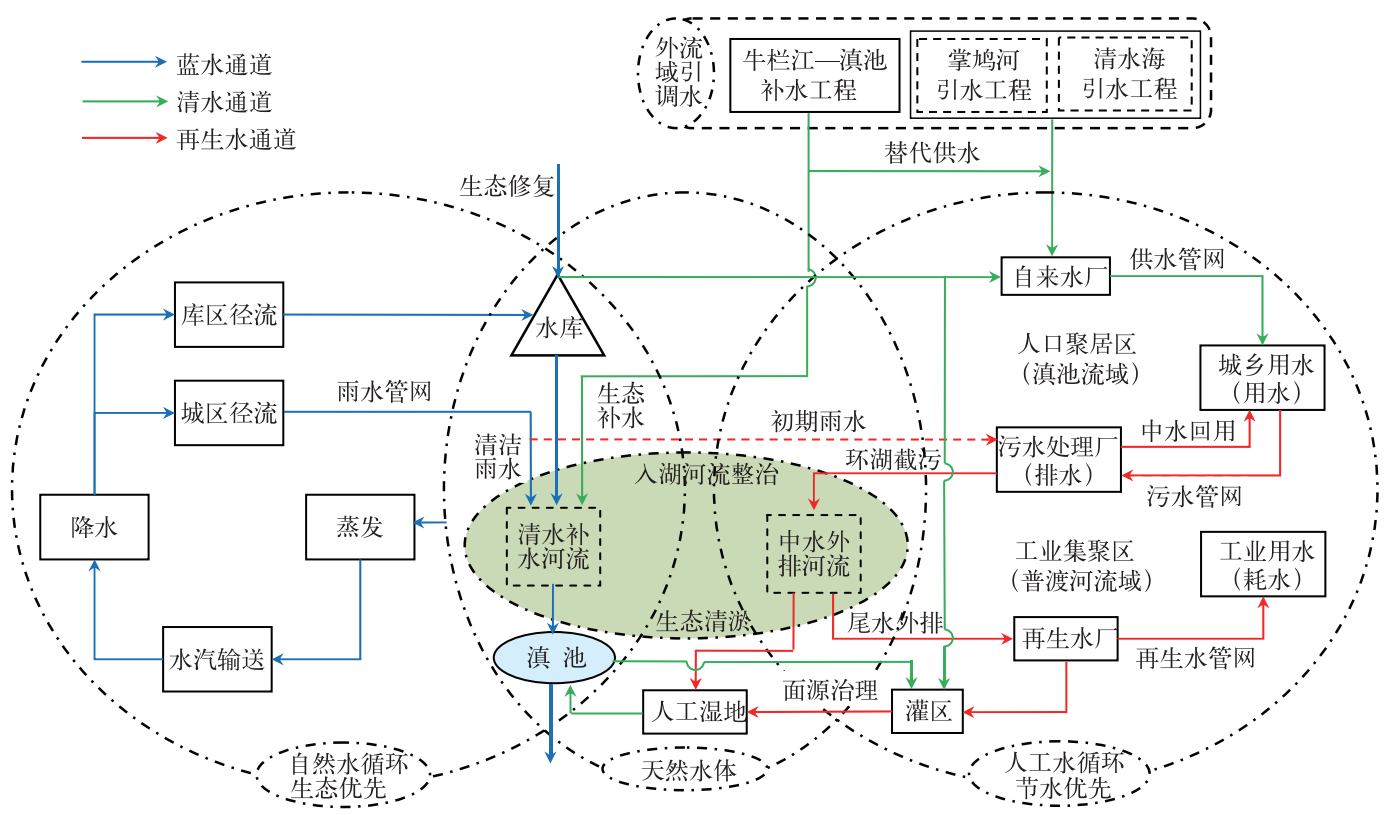

图 2 滇池流域水源水资源综合调控总体框架

Fig.2 Framework for joint disposals of multi-source water resources in Lake Dianchi Basin

年社会经济需水 9.82 亿 $\mathrm{m}^{3}$, 其中城乡生活 5.28 亿 $\mathrm{m}^{3}$, 工业 2.67 亿 $\mathrm{m}^{3}$, 农业灌溉 1.87 亿 $\mathrm{m}^{3}$. 同时, 供水水质 应符合各类用水部门的水质要求.

1.4.2 生态环境系统 城市化及其伴生过程 (城市排水系统建设、土地利用变化等) 对城区河道的基流影响 很显著 ${ }^{[30]}$. 扣除昆明污水处理厂的尾水人河水量后,滇池流域的城区河流枯水期基本处于 “断流” 状态,生 态用水严重短缺, 需要采取措施保障主要人湖河流的生态环境需水. 水质上, 各规划期达到水功能区划的水 质目标: 滇池外海及其主要人湖河流 2020 年达到 IV 类水标准, 2030 年进一步提升到 III类水标准.

\section{5 水资源系统模拟与优化配置模型}

1.5.1 模型选取 本文的关键问题是在资源和环境约束趋紧的背景下, 如何合理配置流域内有限的水资源, 实现流域内多源水的联合调控, 改善区域生态环境, 促进区域经济、社会和环境的协调可持续发展. 目前, 水 资源配置常用的模拟方法大致分为优化模型和规则模型. 优化模型具有概念清晰, 理论基础可靠, 计算结果 整体最优等优点. 但是, 建模过程较繁杂, 尤其应用于研究范围较大的区域时, 存在求解巨型方程组的困难, 动态优化容易陷人 “维数灾” ${ }^{\text {․31] }}$. 规则模型充分发挥了水资源系统符合面向对象技术思想的优势 ${ }^{[32]}$, 建模 过程符合传统的思维习惯, 可移植性强. 滇池流域水资源系统非常复杂, 面临着水资源短缺、水生态退化和 水环境恶化等一系列水问题,对水源管理的要求高 (约束条件多), 优化模型难以满足实际需要. 因此,采用 规则模型 MIKE BASIN 作为本文的水资源配置模拟平台.

1.5.2 模型简介 MIKE BASIN 是丹麦水力研究所 (Danish Hydraulic Institute, DHI) 研发的水资源规划管理决 策支持软件, 在水资源配置、水库调度、农业灌溉调配等方面得到广泛的应用 ${ }^{[33-34]}$. 采用 MIKE BASIN 建立 区域/流域水资源模拟与优化配置模型一般步骤如下:

1) 数字流域构建: 在 ArcGIS 平台上对研究区域的水资源系统进行数字化, 按照河流水系建立河网模 型, 反映干支流、左右岸、上下游关系. 河网模型可通过流域 DEM 数字高程图自行生成详细的水系河网, 也 可先人工概化得到研究区的水资源系统, 再在平台上直接生成概化河网.

2) 输人文件生成:采用水资源分区结合行政分区划分计算单元, 预测各计算单元的城镇生活、工业、农 业灌溉、农村生活、河湖补水等 5 类用户的需水量; 在降雨一径流模块 (NAM 模块) 中输人降水、蒸发等观测 资料, 模拟水库、取水口等汇水节点的径流, 也可将水文径流还原分析得到的径流系列直接输人模型; 各水 
库调度控制水位(死水位、正常水位、汛限水位等)、水位一库容一面积曲线等工程属性,采用 MIKE BASIN 的 前处理软件生成模型输人文件.

3) 节点属性定义: 在河网模型上添加工程、用户、分汇水点、控制性节点等模型节点, 并定义各类节点的 属性. 其中工程节点分为蓄、引、提、调、地下水、污水处理回用等 6 大类, 将各类水源工程的属性导人模型, 规划水平年新建工程可直接添加到相应的河网中. 各计算单元的用户节点一般分为城镇生活、工业、农业灌 溉、农村生活、河湖补水等 5 类, 将预测的各用户的需水过程输人模型. 以供水为主线, 确定各工程节点的供 水对象及供水优先次序. 以用水为主线, 确定各用户节点的供水水源及供水优先次序.

4) 约束条件设定: 根据水资源管理的要求,设定约束条件,例如控制性节点的最小生态流量、河道最大 过流能力、供水线路最大输水能力等.

5) 模型校验修正: 采用现状基准年对模型进行校验, 重点分析控制性节点 (如水文站) 流量过程、工程节 点的供水过程、用户节点的用水过程等模拟结果的合理性.

6) 情景方案模拟: 根据各情景方案 (如不同水平年) 的具体情况, 调整水源工程与用户之间供用水逻辑 关系, 设定模拟起止时间及时间步长 (通常为 1 月) 进行方案模拟. 根据目标函数的要求, 导出相应参数的模 拟结果.

7) 推荐方案比选: 设定目标函数, 反复调整模型参数, 对模型模拟结果进行综合比选, 得到区域/流域水 资源配置的推荐方案.

1.5.3 模型规则 模型规则分为基本规则和运行规则. 基本规则主要包括安全运行规则、用水优先次序、供 水先后次序等, 在模型构建时已在节点属性中确定; 运行规则包括退水及其再生利用规则、水库供水调度规 则、外调水供水规则等.

\section{2 结果与分析}

\section{1 水资源配置模型及验证}

2.1.1 水资源配置模型构建 以水资源四级区套县级行政区, 将滇池流域及其相关区域划分为 12 个计算单 元. 按照流域健康水循环的总体调控方案, 概化得到研究区域各规划期的水资源系统图, 作为 MIKE BASIN 建立模型河网的 “蓝图”. 由于滇池流域及相关区域各水平年水源工程的数量、供水范围和对象不同, 概化的 水资源系统图也有所不同, 滇中引水工程建成通水的 2030 年最复杂, 详见图 3.

2.1.2 模型校验与验证 采用 MIKE BASIN 软件平台对现状水平年进行模拟, 调整模型参数, 使得模拟输出 的结果与各类工程的供水量相符, 验证所建模型的合理性. 从各计算单元的供水量来看, 模型配置的供水量 与实际供水量吻合较好, 相关系数达 0.999 (图 4) ; 从各用水部门的供水量来看, 配置结果与现状各行业的实 际供水基本一致, 相关系数为 0.999 . 这表明本文构建的 MIKE BASIN 水资源配置模型能够很好地模拟滇池 流域的水资源系统,可作为重构滇池流域健康水循环的模拟平台.

\section{2 流域水资源总体配置方案}

2.2.1 城乡供水保障方案 采用已校验好的滇池流域 MIKE BASIN 水资源配置模型, 模拟得到各规划期滇池 流域及相关区域的水资源配置方案, 详见表 2. 滇池流域本区水源工程供水量为 5.05 亿 $\mathrm{m}^{3}$, 水资源开发利用 程度高达 $91.0 \%$, 进一步开发利用本区水资源的潜力十分有限. 城市供水量中外调水的比重由现状的 $44.9 \%$ 逐步增加至 2030 年的 $66.8 \%$, 今后将越来越依靠外流域调水来解决日益增长的用水需求. 按照自然水循环 “生态优先” 的原则, 通过生态调度逐步退还挤占的河湖生态用水, 本区天然来水量用于保障河湖生态用水 的比例从现状的 $9.0 \%$ 增加到 $33.2 \%$, 基本保障了人湖河流的生态基流.

2.2.2 入湖河流生态用水保障方案 通过水库生态调度已满足部分河流的生态需水, 但是盘龙江、洛龙河、马 料河、捞鱼河、梁王河等昆明东部和北部的河流穿城而过, 廊道景观需水量较大, 通过水库生态调度难以满 足这些河流的生态需水. 拟规划新建水系连通工程 (工程布局见图 5), 将牛栏江的生态补水量调配至上述 河流, 向这些河道补水 26870 万 $\mathrm{m}^{3}$. 滇池流域的清水廊道河长达到 $455.0 \mathrm{~km}$, 占流域主要人滇河流干流总河 长的 $77.3 \%$, 集雨面积占流域陆域总面积的 $79.0 \%$, 流域自然水系基本恢复. 同时, 清水廊道的河流水质均为 III类地表水 (与牛栏江外调水的水质一致), 达到 2030 年水功能区的水质目标. 在河道综合整治工程和环湖 


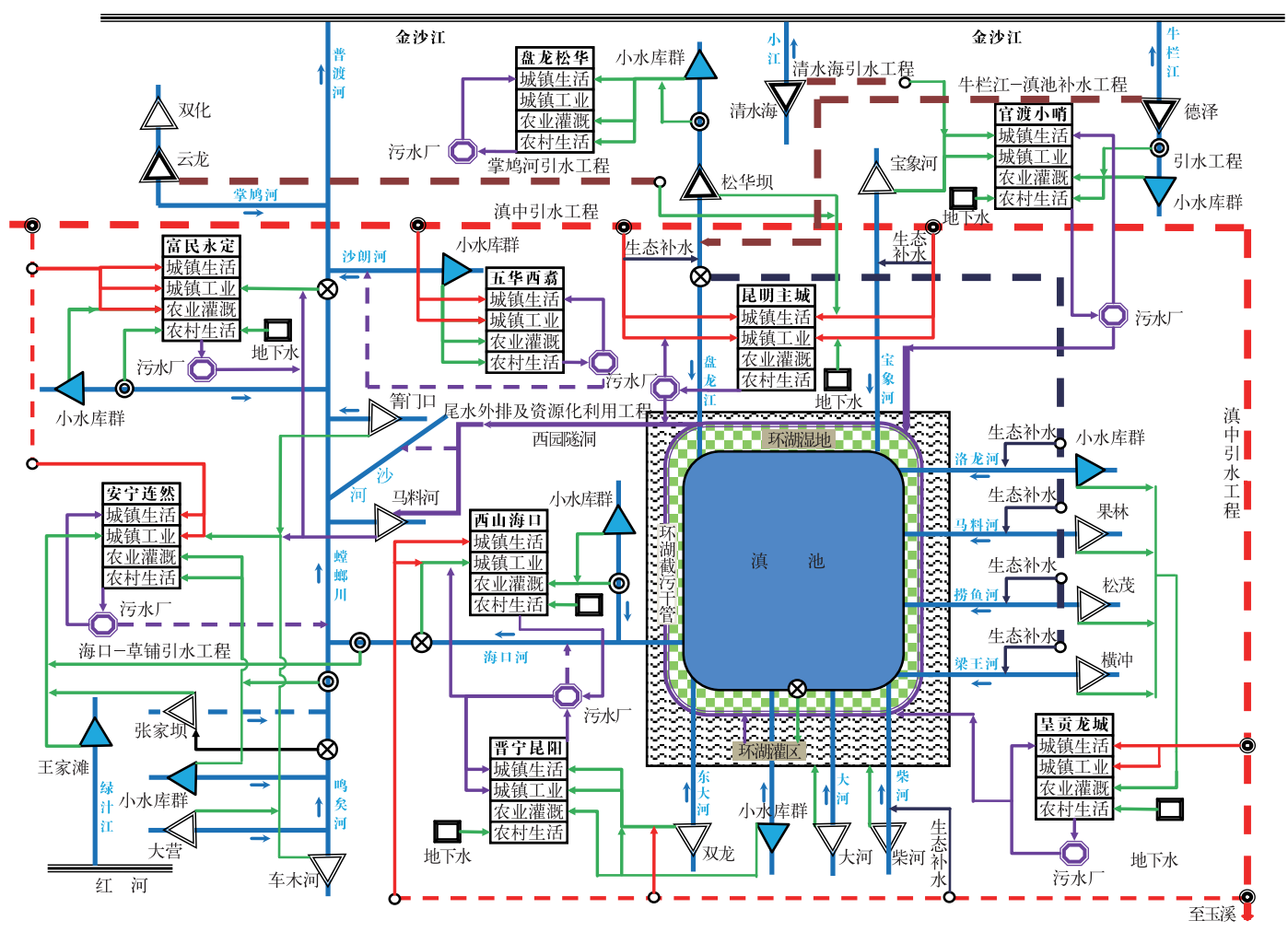

图 32030 年滇池流域及相关区域水资源系统概化图

Fig.3 Conceptual network diagram for water resources system in

Lake Dianchi Basin and its associated regions in 2030
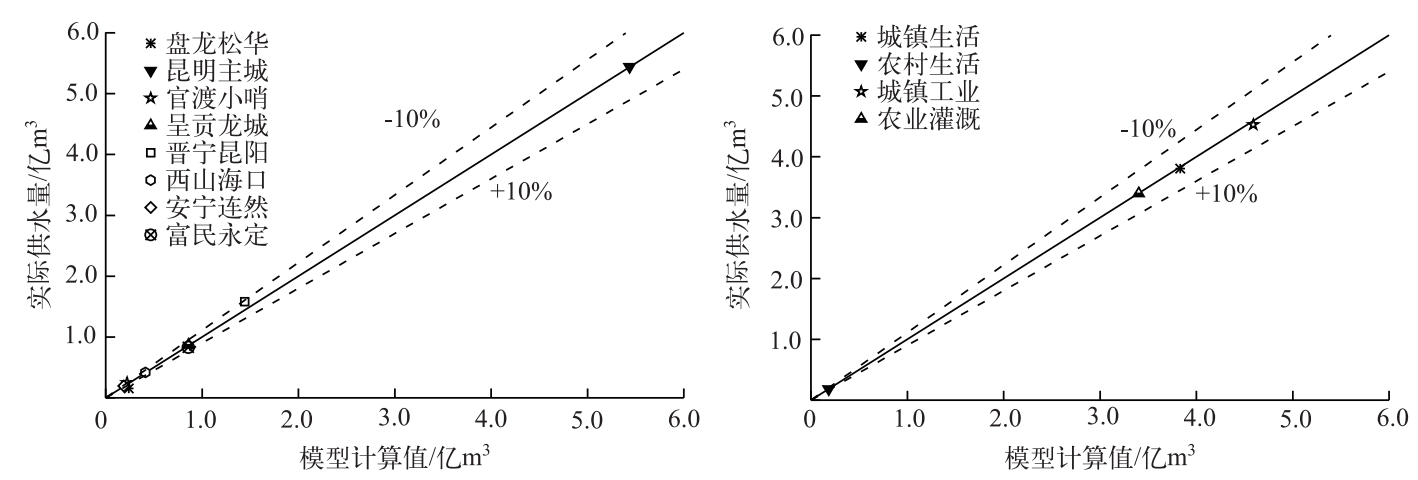

图 4 现状年 MIKE BASIN 模拟结果与实际供水量的对比

Fig.4 Comparisons of simulated results of the proposed MIKE BASIN model with statistical data

湿地 (生态建设与修复工程) 的配合下, 保障清水入湖, 恢复流域清水产流机制, 对滇池湖体水质的持续改善 具有重要意义.

\section{3 基于滇池水量平衡的尾水外排方案}

2.3.1 污水减负及资源化利用方案 受工业布局调整和配套管网不完善的影响, 目前滇池流域的再生水回用 率还比较低, 主要用于市政杂用、绿化浇酒和河道补水等方面 ${ }^{[29]}$. 昆明市工业今后主要布局在滇池下游的 
安宁一富民工业走廊, 再生水需求主要集中在滇池下游. 因此, 采取再生水跨区域配置( 尾水外排及资源化 利用) 提高再生水回用率. 根据园区产业发展规划, 预测 2020 年安宁一富民工业走廊的工业需水高达 4.23 亿 $\mathrm{m}^{3}$, 布局的火力发电、钢铁冶炼等产业循环冷却用水可利用再生水, 再生水需求量为 1.14 亿 $\mathrm{m}^{3}$, 扣除本区 再生水利用量 0.11 亿 $\mathrm{m}^{3}$, 还可利用滇池流域外排的尾水 1.03 亿 $\mathrm{m}^{3} .2020$ 年滇池流域再生水产生量为 4.15 亿 $\mathrm{m}^{3}$, 市政用水消耗 0.55 亿 $\mathrm{m}^{3}$, 河道生态补水消耗 0.06 亿 $\mathrm{m}^{3}$ (水面蒸发水量), 加上外排资源化利用量 1.03 亿 $\mathrm{m}^{3}$, 滇池流域再生水回用率将达到 $39.5 \%$, 接近发达国家的污水回用水平.

表 2 滇池流域及下游安宁一富民工业走廊水资源供需平衡方案

Tab.2 Demand-supply balance of water resources in Lake Dianchi Basin and its associated regions

\begin{tabular}{|c|c|c|c|c|c|c|c|c|c|c|c|c|c|c|}
\hline \multirow{3}{*}{ 计算区域 } & \multirow{3}{*}{ 水平年 } & \multicolumn{4}{|c|}{ 需水量/亿 $\mathrm{m}^{3}$} & \multicolumn{8}{|c|}{ 供水量/亿 $\mathrm{m}^{3}$} & \multirow{3}{*}{$\begin{array}{c}\text { 缺水率/ } \\
\%\end{array}$} \\
\hline & & \multirow[b]{2}{*}{$\begin{array}{l}\text { 城乡 } \\
\text { 生活 }\end{array}$} & \multirow[b]{2}{*}{$\begin{array}{l}\text { 城镇 } \\
\text { 工业 }\end{array}$} & \multirow[b]{2}{*}{$\begin{array}{l}\text { 农业 } \\
\text { 灌溉 }\end{array}$} & \multirow[b]{2}{*}{ 合计 } & \multicolumn{4}{|c|}{ 本区水源工程 } & \multicolumn{2}{|c|}{ 外调水工程 } & \multirow[b]{2}{*}{$\begin{array}{l}\text { 污水处 } \\
\text { 理回用 }\end{array}$} & \multirow[b]{2}{*}{ 合计 } & \\
\hline & & & & & & $\begin{array}{l}\text { 蓄水 } \\
\text { 工程 }\end{array}$ & $\begin{array}{l}\text { 引水 } \\
\text { 工程 }\end{array}$ & $\begin{array}{l}\text { 提水 } \\
\text { 工程 }\end{array}$ & $\begin{array}{c}\text { 地下水 } \\
\text { 工程 }\end{array}$ & $\begin{array}{l}\text { 引水 } \\
\text { 济昆 }\end{array}$ & $\begin{array}{l}\text { 滇中 } \\
\text { 引水 }\end{array}$ & & & \\
\hline \multirow[t]{3}{*}{ 滇池流域 } & 现状 & 3.54 & 2.58 & 2.34 & 8.46 & 2.76 & 0.22 & 1.42 & 0.71 & 2.75 & 0.00 & 0.34 & 8.20 & 3.1 \\
\hline & 2020 & 4.42 & 2.55 & 2.00 & 8.97 & 2.66 & 0.19 & 1.59 & 0.58 & 3.27 & 0.00 & 0.55 & 8.83 & 1.5 \\
\hline & 2030 & 5.28 & 2.67 & 1.87 & 9.82 & 2.33 & 0.11 & 1.04 & 0.22 & 1.09 & 4.22 & 0.72 & 9.74 & 0.8 \\
\hline \multirow{3}{*}{$\begin{array}{c}\text { 安宁－富民 } \\
\text { 工业走廊 }\end{array}$} & 现状 & 0.45 & 1.88 & 1.28 & 3.60 & 1.30 & 0.28 & 1.51 & 0.46 & 0.00 & 0.00 & 0.00 & 3.56 & 1.1 \\
\hline & 2020 & 0.63 & 4.23 & 1.42 & 6.28 & 1.94 & 2.29 & 0.76 & 0.02 & 0.00 & 0.00 & 1.14 & 6.16 & 1.9 \\
\hline & 2030 & 0.87 & 5.60 & 1.58 & 8.05 & 1.39 & 0.23 & 0.48 & 0.02 & 0.00 & 4.42 & 1.44 & 7.99 & 0.8 \\
\hline
\end{tabular}

2.3.2 城市尾水外排水量分析 2013 年 12 月底, 牛栏江一滇池补水工程建成通水, 通过盘龙江年均向滇池生 态补水 5.72 亿 $\mathrm{m}^{3}$, 大致相当于滇池流域的水资源总量, 大幅提高了滇池调度的灵活性. 同时, 昆明市尾水外 排及资源化利用二期工程已经实施完成, 由环湖截污北岸干管收集大清河、采莲河等尾水通道输送的城市 尾水 77.5 万 $\mathrm{m}^{3} / \mathrm{d}$, 经西园隧洞外排出滇池流域. 研究表明,外流域生态补水后削减人湖污染负荷仍是改善 滇池湖体水质和修复滇池水环境的根本途径 ${ }^{[15]}$. 在维持滇池水量平衡的前提下, 尾水尽量外排不进人滇 池, 是削减人湖污染负荷的主要途径之一. 本文拟定 3 个情景分析确定尾水外排的水量: 1) 全部外排方案, 2020 水平年城市尾水全部外排;2) 按需外排方案,按照下游工业园区的再生水需求量外排,其余尾水进人滇 池;3) 全部人湖方案,城市尾水全部进人滇池. 各方案滇池水位的模拟结果见表 3.

表 32020 年不同尾水外排方案下滇池水量平衡

Tab.3 Water balance of Lake Dianchi under different scenarios in 2020 target year of planning

\begin{tabular}{|c|c|c|c|c|c|c|c|c|c|c|c|c|c|c|}
\hline \multirow[b]{2}{*}{ 情景方案 } & \multicolumn{6}{|c|}{ 人湖水量/亿 $\mathrm{m}^{3}$} & \multicolumn{4}{|c|}{ 出湖水量/亿 $\mathrm{m}^{3}$} & \multicolumn{2}{|c|}{ 水位特征/m } & \multirow{2}{*}{$\begin{array}{c}\text { 蓄变量/ } \\
\text { 亿 } \mathrm{m}^{3}\end{array}$} & \multirow{2}{*}{$\begin{array}{c}\text { 蓄满率/ } \\
\%^{3)}\end{array}$} \\
\hline & $\begin{array}{l}\text { 湖面 } \\
\text { 降水 }\end{array}$ & $\begin{array}{l}\text { 陆面 } \\
\text { 径流 }\end{array}$ & $\begin{array}{l}\text { 生态 } \\
\text { 补水 }^{1)}\end{array}$ & $\begin{array}{l}\text { 农业 } \\
\text { 退水 }\end{array}$ & $\begin{array}{l}\text { 城市 } \\
\text { 尾水 }\end{array}$ & 合计 & $\begin{array}{l}\text { 湖面 } \\
\text { 蒸发 }\end{array}$ & $\begin{array}{c}\text { 环湖 } \\
\text { 耗水 }^{2)}\end{array}$ & $\begin{array}{c}\text { 海口河 } \\
\text { 出流 }\end{array}$ & 合计 & $\begin{array}{l}\text { 平均 } \\
\text { 水位 }\end{array}$ & $\begin{array}{l}\text { 最低 } \\
\text { 水位 }\end{array}$ & & \\
\hline 全部外排 & 2.83 & 5.68 & 5.39 & 0.58 & 0.00 & 14.48 & 4.52 & 1.78 & 8.16 & 14.46 & 1887.12 & 1886.10 & 0.02 & 34.08 \\
\hline 部分人湖 & 2.83 & 5.68 & 5.39 & 0.58 & 2.51 & 16.99 & 4.52 & 1.78 & 10.67 & 16.97 & 1887.15 & 1886.11 & 0.02 & 35.12 \\
\hline 全部人湖 & 2.83 & 5.68 & 5.39 & 0.58 & 3.54 & 18.02 & 4.52 & 1.78 & 11.70 & 18.00 & 1887.17 & 1886.14 & 0.02 & 37.20 \\
\hline
\end{tabular}

1) 为外流域补水量扣除清水廊道的水面蒸发、通河湿地耗水后的实际人湖水量; 2) 包括环湖湿地耗水、环湖提灌水量和 环湖工业提水量; 3 ) 为湖泊水位达到控制运行水位的比率,其中汛期控制水位为汛限水位,其余月份为正常高水位.

采用滇池的平均水位、最低水位和蓄满率来进行方案比选. 由表 3 可见, 由于城市尾水比较均匀, 对滇 池运行水位的影响很小. 尾水全部外排方案, 滇池平均水位为 $1887.12 \mathrm{~m}$,最低水位为 $1886.10 \mathrm{~m}$, 蓄满率为 $34.08 \%$,水位在汛限水位附近波动, $90.8 \%$ 的月份水位在 $1886.70 \sim 1887.50 \mathrm{~m}$ 之间呈周期性变动 (图 6), 有利 于湖体水质改善和环湖湿地的运行管理 ${ }^{[15,35]}$. 在牛栏江一滇池补水工程生态补水 5.72 亿 $\mathrm{m}^{3}$ 的前提下, 滇池 流域城市尾水全部外排不再进入滇池, 可大幅削减滇池入湖污染负荷总量 ${ }^{[13]}$. 因此, 本文提出的 “外调水一 


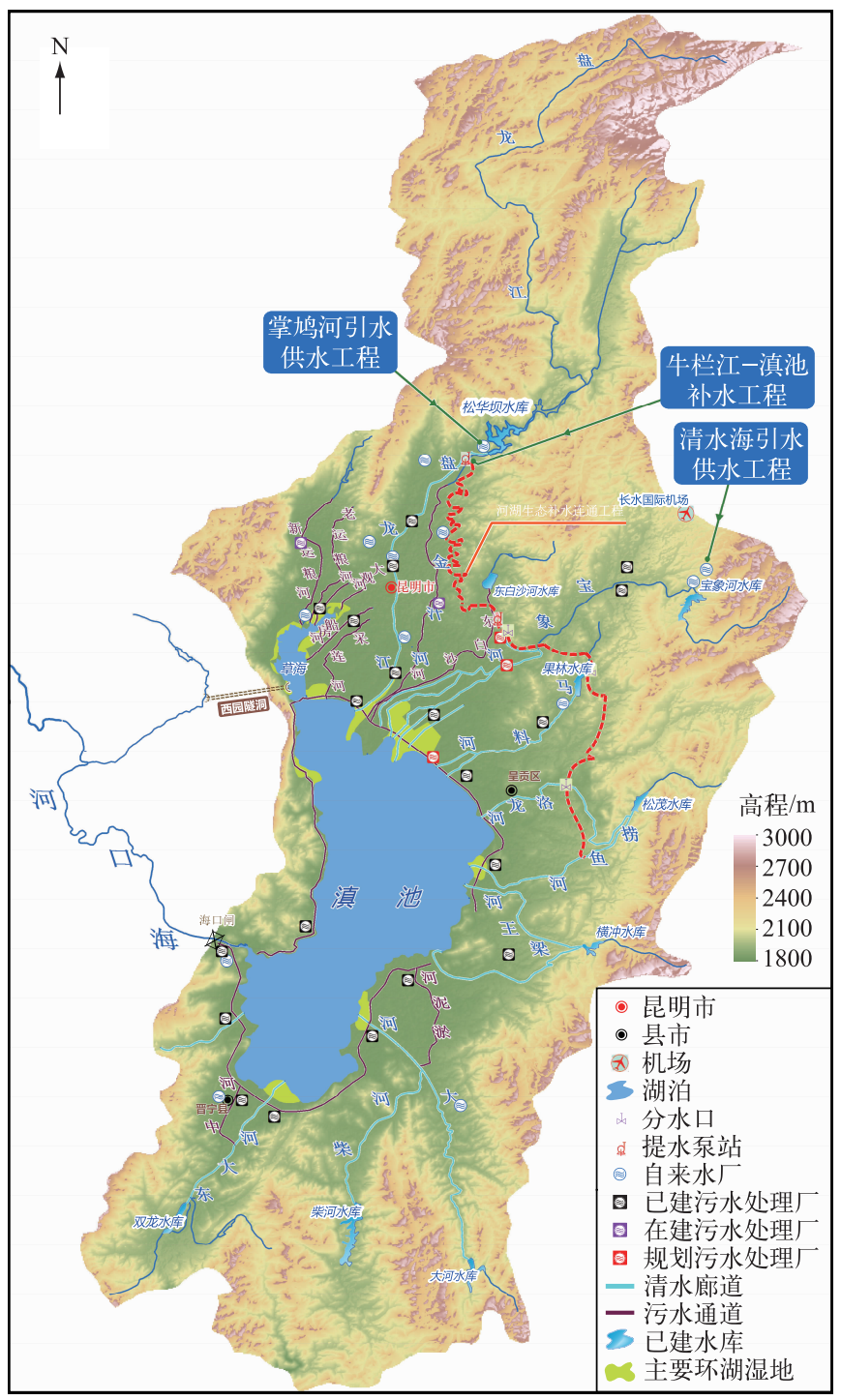

图 5 滇池流域健康水循环总体布局

Fig.5 General layout of healthy water cycle in Lake Dianchi Basin

自来水厂一用户一污水处理厂一尾水外排河流一截污干管一西园隧洞一下游工业园区水厂”循环路径 (图 2), 能够避免循环通量日益增长的社会水循环对自然水循环的干扰, 保障清水人湖, 有利于流域水体水质的改 善和河湖功能的生态修复.

2030 水平年, 牛栏江一滇池补水工程转供曲靖 3.10 亿 $\mathrm{m}^{3}$, 向滇池的生态补水量减为 1.38 亿 $\mathrm{m}^{3}$, 缺口由 滇中引水工程解决, 共同向滇池生态补水 7.00 亿 $\mathrm{m}^{3}$, 大于 2020 水平年的湖泊补水量. 因此, 2030 水平年滇 池流域的城市尾水也可全部外排.

\section{3 结论和建议}

本文在系统调查滇池流域水资源系统和水环境治理现状的基础上,对流域水问题进行了系统诊断, 提 出了滇池流域健康水循环模式的总体框架. 采用规则模型 MIKE BASIN 建立滇池流域水资源水质水量联合 


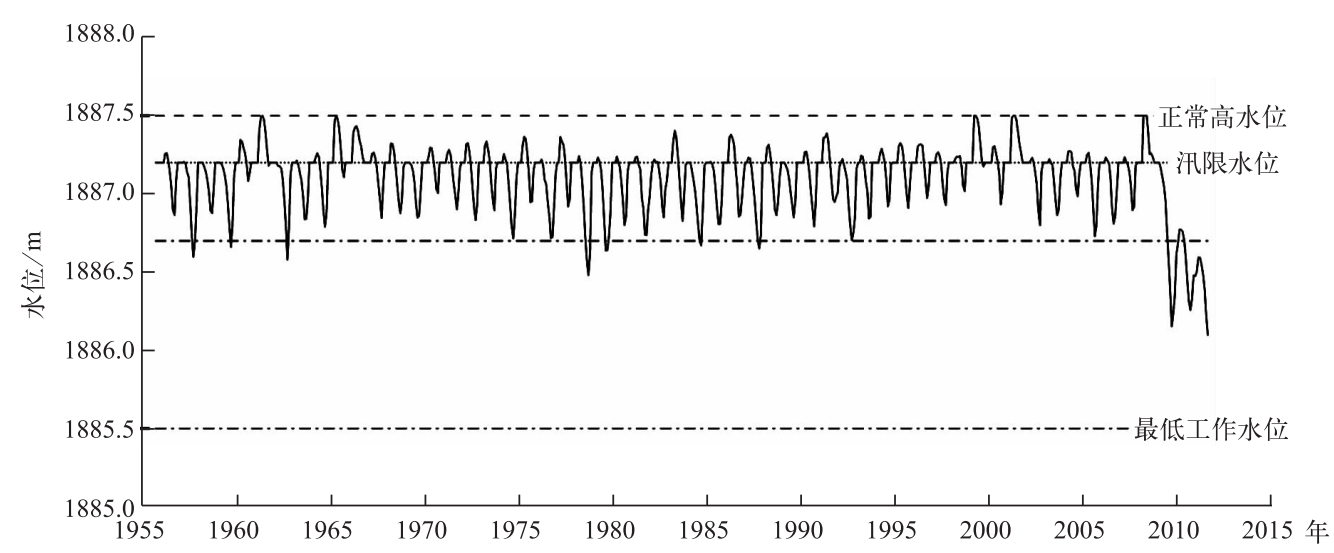

图 62020 水平年城市尾水全部外排方案中滇池水位模拟结果

Fig. 6 Simulated results of water level of Lake Dianchi in 2020 target year of planning

调度的模拟模型, 通过对水库水、湖泊水、地下水、外调水、再生水等多源水资源联合配置, 提出了调整流域 社会水循环路径和通量的具体方案,恢复滇池流域的自然水系循环. 主要的研究结论和建议如下:

1) 厘清现状紊乱的河湖功能, 确定清水廊道和尾水通道, 在流域尺度上实现 “清污分流”, 是重构滇池流 域健康水循环的关键. 建议在今后的河流管理中,严格按照各类河流的功能进行分类管理.

2) 保障河流生态用水是河流生态恢复的核心任务, 本文采取水库生态调度、水系连通补水、再生水回补 3 种方式分类解决滇池入湖河流的生态用水, 其中清水廊道河段总长占流域总长的 $70.3 \%$. 结合河道整治工 程打造清水通道, 确保清水河流的水质不低于牛栏江外调水的 III 类地表水, 提前达到 2030 年水功能区的水 质目标.

3) 为了削减滇池人湖污染负荷, 城市尾水应尽量直接外排, 尾水外排量取决于滇池水量平衡. 在外流域 调水工程未实施前, 城市尾水只有排人滇池, 才能维持湖泊的水量平衡. 在牛栏江一滇池补水工程多年平均 向滇池补水 5.72 亿 $\mathrm{m}^{3}$ 的前提下, 滇池依靠清洁水量已能维持湖泊水量平衡, 不再需要城市尾水的补给,城 市尾水可以全部外排. 2030 年,牛栏江一滇池补水工程转供曲靖市,滇池生态补水主要由滇中引水工程解 决,生态补水量大于牛栏江一滇池补水工程的补水量,城市尾水也可全部直接外排,不再进人滇池.

4) 受产业结构和布局调整的影响, 滇池流域的再生水现状主要用于市政杂用, 回用率较低. 滇池下游的 安宁一富民工业走廊正在建设国家级产业新区,用水需求将大幅增长, 通过再生水跨区域配置, 将昆明城市 尾水外排作为下游园区的工业用水, 是提高昆明市再生水利用率、削减污染物人湖量的有效途径.

\section{4 参考文献}

[ 1 ] Qin BQ, Gao G, Hu WP et al. Reflections on theory and practice of shallow lake ecosystem restoration. J Lake Sci, 2005, 17 (1) : 9-16. DOI: 10.18307/2005.0102. [秦伯强, 高光, 胡维平等. 浅水湖泊生态系统恢复的理论与实践思考. 湖泊科学, $2005,17(1): 9-16$. ]

[ 2 ] Yang GS, Ma RH, Zhang L et al. Lake stats, major problems and protection strategy in China. J Lake Sci, 2010, 22 (6) : 799-810. DOI: 10.18307/2010.0601. [杨桂山, 马荣华, 张路等. 中国湖泊现状及面临的重大问题与保护策略. 湖 泊科学, 2010,22(6): 799-810.]

[ 3 ] Liu JH, Qin DY, Wang H et al. Dualistic water cycle pattern and its evolution in Haihe River basin. Chinese Science Bulletin, 2010, 55(16): 1668-1697.

[ 4 ] Wang H, Jia YW, Yang GY et al. Integrated simulation of the dualistic water cycle and its associated processes in the Haihe River Basin. Chinese Science Bulletin, 2013, 58(27) : 3297-3311.

[ 5 ] Qin DY, Lu CY, Liu JH et al. Theoretical framework of dualistic nature-social water cycle. Chinese Science Bulletin, 2014, 59(4/5) : 419-427. 
[ 6 ] Zhang J, Xiong BY. The implementation strategy for urban healthy water cycle. Journal of Beijing University of Technology, 2004, 30(2) : 185-189. [张杰, 熊必永. 城市水系统健康循环的实施策略. 北京工业大学学报, 2004, 30 (2) : 185-189.]

[ 7 ] Zhang J, Li D. Watershed and urban healthy water cycle strategic planning. Water \& Wastewater Engineering, 2008,34 (5) : 136-146. [张杰, 李冬. 流域和城市健康循环战略规划实例. 给水排水, 2008, 34(5): 136-146.]

[ 8 ] Jia GN, Huang P, Wen C. New strategy on comprehensive water control based on healthy water circulation concept in Panyu district. China Water \& Wastewater, 2012, 28(20): 20-23. [贾国宁, 黄平, 温聪. 基于健康水循环理念的番禺区 综合治水新策略探讨. 中国给水排水, 2012, 28(20): 20-23.]

[ 9 ] Zhang J, Li D. Study on water environment restoration and urban water system healthy circulation. Water \& Wastewater Engineering, 2008, 34(5) : 136-146. [张杰, 李冬. 水环境恢复与城市水系健康循环研究, 中国工程科学, 2008,34 (5) : 136-146.]

[10] Wang XF, Liu H, Yuan XZ et al. Construction of the urban water environmental pollution control system based on the ecological ideas of water sensitive urban design. Acta Ecologica Sinica, 2016, 36(1): 30-43. [王晓锋, 刘红, 袁兴中等. 基于水敏性城市设计的城市水环境污染控制体系研究. 生态学报, 2016, 36(1):30-43.]

[11] Fryd O, Backhaus A, Birch H et al. Water sensitive urban design retrofits in copenhagen-40\% to the sewer, $60 \%$ to the city. Water Science \& Technology, 2013, 67(9) : 1-21. DOI: 10.2166/wst.2013.073.

[12] Donofrio J, Kuhn Y, McWalter K et al. Water-sensitive urban design: An emerging model in sustainable design and comprehensive water-cycle management. Environmental Practice, 2009, 11(3) : 179-189.

[13] He J, Xu XM, Yang Y et al. Problems and effects of comprehensive management of water environment in Lake Dianchi. $J$ Lake Sci, 2015, 27(2): 195-199. DOI: 10.18307/2015.0201. [何佳, 徐晓梅, 杨艳等. 滇池水环境综合治理成效与 存在问题. 湖泊科学, 2015, 27(2): 195-199.]

[14] Li ZJ, Zhen YX, Zhang DW et al. Impacts of 20-year socio-economic development on aquatic environment of Lake Dianchi. J Lake Sci, 2012, 24(6) : 875-882. DOI: 10.18307/2012.0610. [李中杰, 郑一新, 张大为等. 滇池流域近 20 年 社会经济发展对水环境的影响. 湖泊科学, 2012, 24(6): 875-882.]

[15] Liu Y, Wang Y, Sheng H et al. Quantitative evaluation of lake eutrophication responses under alternative water diversion scenarios: A water quality modeling based statistical analysis approach. Science of the Total Environment, 2014, 468/469: 219-227.

[ 16] Xu XM, Wu X, He J et al. Research on the pollution characteristics of Dianchi watershed (1988-2014) and identification of countermeasures. J Lake Sci, 2016, 28(3) : 476-484. DOI: 10.18307/2016.0302. [徐晓梅, 吴雪, 何佳等. 滇池流 域水污染特征( 1988-2014 年) 及防治对策. 湖泊科学, 2016, 28(3) : 476-484.]

[17] Shi JP, Li X. Water environment carrying capacity in Dianchi Lake basin and its dynamic variation characteristics. Acta Scientiae Circumstantiae, 2012, 32(7) : 1777-1784. [石建屏, 李新. 滇池流域水环境承载能力及其动态变化特征研 究. 环境科学学报, 2012, 32(7): 1777-1784.]

[18] Wang Z, Zou R, Zhu X et al. Predicting lake water quality responses to load reduction: A three-dimensional modeling approach for total maximum daily load. Int J Environ Sci Te, 2014, 11(1/2/3/4) : 423-436.

[19] Wu LQ, Pan YX, Zhu YG et al eds. Rivers and lakes in Yunnan. Kunming: Yunnan Science and Technology Press, 2010: 28-43. [伍立群, 潘一学, 朱远高等. 云南河湖. 昆明: 云南科技出版社, 2010: 28-43.]

[20] Li JX, Liu SK, Li SJ. The simulating and analyzing of the effects of the project Xiyuan Tunnel on the COD ${ }_{\text {Mn }}$ concentrations in Dianchi Lake. J Lake Sci, 1998, 10(2): 78-84. DOI: 10.18307/1998.0213. [李锦秀, 刘树坤, 李术军. 西园 隧洞引水工程对滇池 $\mathrm{COD}_{\mathrm{Mn}}$ 的影响分析. 湖泊科学, 1998, 10(2) : 78-84.]

[21] Mao JZ, Sun YL, He KD et al. Study of water environment improvement effect by Niulan River-Dianchi Lake Water Supplement Project in Waihai area of Dianchi Lake. Water Resources Protection, 2017, 33(2) : 47-51. [毛建忠, 孙燕利, 贺 克雕等. 牛栏江一滇池补水工程对滇池外海的水环境改善效果研究. 水资源保护, 2017, 33(2): 47-51.]

[22] Zhou J, Wang J, Wang P et al. Wavelet analysis of water quality changes in Dianchi Lake during the past 7a. Procedia Earth and Planetary Science, 2012, 5: 280-288. DOI: 10.1016/j.proeps.2012.01.048.

[23] Qiu MH, Wang HL. Design scheme of wastewater interception project around Dianchi Lake. China Water \& Wastewater, $2015,31(12)$ : 56-59. [邱明海, 王海玲. 滇池环湖截污工程设计技术方案. 中国给水排水, 2015, 31 ( 12): 56-59. ] 
[24] Yu Q, Chen Y, Liu Z et al. Longitudinal variations of phytoplankton compositions in lake-to-river systems. Limnologica, 2016, DOI: 10.1016/j.limno.2016.02.007.

[25] Deng W, Chen G, Wang XP et al. Wetland ecological water demand in Lake Dianchi Waihai. Journal of Irrigation and Drainage, 2016, 35 (1) : 99-104. [邓雯, 陈刚, 王肖鹏等. 滇池外海环湖湿地生态需水研究. 灌溉排水学报, 2016, 35(1): 99-104.]

[26] Li S, He J, Xu XM et al. River regulation in Lake Dianchi basin: development and perspectives. Environmental Science \& Technology, 2016, 39(S1) : 131-136. [李森, 何佳, 徐晓梅等. 滇池流域河道整治的发展与展望. 环境科学与技 术, 2016, 39(S1) : 131-136.]

[27] Zhang XZ, Jin ZJ, Kong DP et al. The effect of sewage treatment plant effluent on the water quality of urban river in Dianchi watershed: a case study of Daqing River. Journal of Fudan University: Natural Science, 2014, 53(2) : 255-259. [ 张 先智, 金竹静, 孔德平等. 污水处理厂出水的回补对滇池流域典型城区河道一大清河的影响. 复旦学报, 2014, $\mathbf{5 3}(2): 255-259$.]

[28 ] Wu ZF, Li SP, Li W et al. Feasibility analysis of gasification utilization of entropic Lake Dianchi dredged sediment. Journal of Kunming University of Science and Technology: Natural Science, 2016, 41(1) : 64-68. [吴桢芬, 李世平, 李雯 等. 富营养化湖泊滇池疏浚底泥气化利用可行性分析. 昆明理工大学学报：自然科学版, 2016, 41(1) : 64-68.]

[29] Li ZJ, Zhen YX, Zhang DW et al. Analysis of reclaimed water resources utilization characteristics and benefits in the Dianchi Lake Basin. Environmental Science \& Technology, 2016, 35(3): 12-17. [李中杰, 郑一新, 张大为等. 滇池流域再 生水资源现状利用特征及效益分析. 环境科学导刊, 2016, 35(3): 12-17.]

[30] Findlay SJ, Taylor MP. Why rehabilitate urban river systems? Area, 2006, 38(3): 312-325.

[31] You JJ, Gan H, Wang H et al. SimulatiPon of water resources system based on rules. Journal of Hydraulic Engineering, 2005, 36(9) : 1043-1056. [游建军, 甘泓, 王浩等. 基于规则的水资源系统模拟. 水利学报, 2005, 36 (9): 1043-1056.

[32] Reitsma RF, Carron JC. Object-oriented simulation and evaluation of river basin operations. Journal of Geographic Information and Decision Analysis, 1997, 1(1): 9-24.

[33] Gu SX, Li YH, He DM et al. Watershed water resources three-allocation based on MIKE BASIN. Journal of Water Resources \& Water Engineering, 2007, 18(1) : 5-10. [顾世祥, 李远华, 何大明等. 以 MIKE BASIN 实现流域水资源三 次供需平衡. 水资源与水工程学报, $2007, \mathbf{1 8}(1): 5-10$.]

[34] Jha MK, Das GA. Application of Mike Basin for water management strategies in a watershed. Water International, 2003, $28(1): 27-35$.

[35] Liu Y, Guo HC, Zhou F et al. Role of water level fluctuation on aquatic vegetation in lakes. Acta Ecologica Sinica, 2006, 26(9): 3117-3126. [刘永, 郭怀成, 周丰等. 湖泊水位变动对水生植被的影响机理及其调控方法. 生态学报, 2006, 26(9) : 3117-3126.] 